Report 2001-5

Report on a

\title{
Proposal for a
}

Programme of Research ,

in Education

in Afghanistan

David Stephens, Lins

Oslo, August 2001

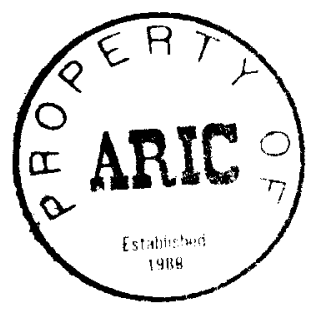




\section{Acknowledgements}

Making a trip to Afghanistan is not easy and I wish to record my thanks to a number of people and organisations who went out of their way to welcome me and to assist me. The fact that I saw so much in a relatively short space of time is due to their help.

In particular I should like to thank Chris Johnson, Director of the SMU for inviting me, and her able colleagues in the field: Brishkai and Faisal in Islamabad and Joyenda in Kabul (who was my guide and friend)

Thanks also to all the people I met working hard for the improvement of children's lives in Afghanistan, especially the teachers and community leaders I met in Logar, on the Logar Road, and Bagrami.

A particular thank you to Ellen van Kalmthout of UNICEF for providing me with tea and a suitcase of supporting documents.

Finally warm thanks to my colleague and friend, Helen Kirby of Save the Children, USA who looked after me and provided me with many stimulating ideas.

\section{David Stephens}

\section{Oslo}

\section{Äugust, 2001}

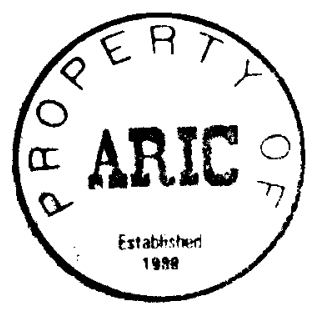




\section{REPORT TO THE STRATEGIC MONITORING UNIT \\ (AFGHANISTAN), AUGUST 2001}

\section{A PROPOSAL FOR A PROGRAMME OF RESEARCH IN EDUCATION}

\section{CONTENTS}

1. INTRODUCTION AND TERMS OF REFERENCE

2. BACKGROUND AND CONTEXTS

2.1. CONTEXT 1: THE CHANGING SITUATION OF CHILDREN AND SCHOOLING IN AFGHANISTAN ....................6

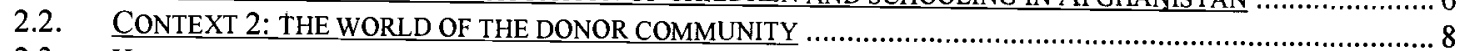

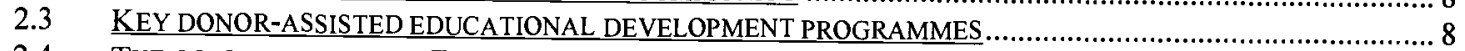

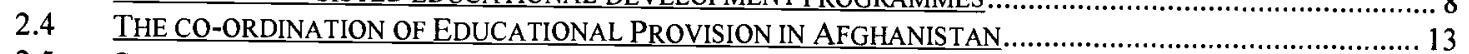

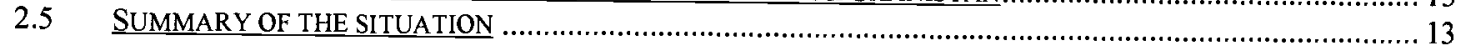

3. THE LANGUAGE OF POSSIBILITY: PROPOSALS FOR A RESEARCH PROGRAMME IN EDUCATION

\begin{tabular}{|c|c|}
\hline 3.1. & THE PROPOSAL .... \\
\hline 3.2 & QWERVIEW .......... \\
\hline 3.3 & GOAL ….............................. \\
\hline 3.4 & 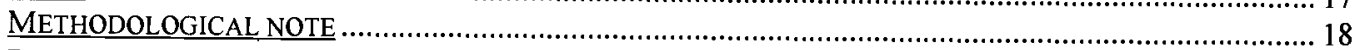 \\
\hline 3.5 & PURPOSE \\
\hline 3.6 & OUTPUTS AND THEIR CONTRIBUTION \\
\hline 3.7 & ACTIVITIES \\
\hline 3.8 & BENEFICIARIES \\
\hline .9 & RISKS AND ASSUMPTIONS \\
\hline
\end{tabular}

\section{Appendices}

A Outline Log Frame for Education Research Programme

B Key Individuals and Organisations met 


\section{Introduction and terms of reference}

This report is a proposal to the Strategic Monitoring Unit (SMU) to consider a programme of research in education. The report is based upon an initial intensive visit to Pakistan and Afghanistan (July 2001) during which discussions were held with key individuals and agencies active in education, (see Appendix B). Limited visits were made to educational provision in the field, and documentation was procured from interested stakeholders working to provide and improve the quality of education for children in Afghanistan.

The objectives of the visit were to produce for the SMU Board a report covering the following:

* The key issues in education in Afghanistan.

* The way in which education provision for Afghans in neighbouring countries relates to provision inside Afghanistan.

* The main areas in which further research and analysis are needed.

* Recommendations for the programme of research that SMU should be carrying out over the next two or three years, how this could be taken forward, and how it would relate to the work of other agencies active in education.

Time and logistical difficulties meant that it was not possible on this visit to meet with individuals and projects in non-Taliban controlled areas (Badakhshan) or those working in the provision of education for Afghan refugees in Pakistan. The purpose of this current proposal, therefore, is to produce a broad concept paper with a final proposal on the scope of the research to be made after a further visit to meet with interested parties in those areas.

Paulo Freire, the radical Brazilian educationist talked about the "two languages" of educational development: the language of critique i.e. a clear understanding of where we stand with regard to the education of children, teaching, facilities, alternatives etc; and the language of possibility i.e. directions, ways forward, proposals for change.

It seems useful and appropriate to use these "two languages" in the structuring of this report:

- critique: to provide a succinct critical overview of the landscape of educational provision within Kabul and outlying areas visited in July with some indication of the relative strengths and weaknesses of this provision

- possibility: to suggest possible ways forward in terms of a research programme linked to the overall objectives of interested parties i.e. the people and authorities within Afghanistan, the agencies providing schooling within and without the country, and the SMU

This report presents a strategy for developing educational research in Afghanistan over the next two to three years. The SMU is supporting similar research efforts in the development of a livelihoods monitoring programme in Afghanistan.

In terms of general approach this education report shares and supports the approach taken in the livelihoods study, namely "... an approach seeking to strike an appropriate balance between "process" and "product", being concerned about the means of reaching desirable objectives as well as the outputs itself. It is informed by an awareness of the contestation and 
debate that exists amongst key players, donors versus implementers, UN agencies versus bilateral agencies, UN agencies versus NGO's, over both principles and practice. The proposal takes no position with respect to this debate but seeks to establish a process by which arguments, positions, policy and practice can be more fully informed than they are at present by critical evidence from "the field".

\section{Background and contexts}

The SMU Board has agreed in principle that education should be considered as a priority area for sectoral work. Through some limited data on access has already been produced through area studies, the key question now is what in-depth analysis of various aspects of education needs to be done through specific studies.

With little, if any, support for education from the authorities (in either Taliban or non-Taliban areas) a number of agencies have developed significant programmes of work in the provision of education and improvements in the quality of that provision

There is therefore a strong case to be made for basing a research programme in eduçation upon the initiatives of significant agencies (particularly where an effort has been made in an inter-agency collaborative fashion) and in looking at generalisable lessons which may be applied across the sector.

With this in mind an effort was made during the initial visit to Afghanistan to learn about the work of leading agencies promoting education and to assess the possibilities of developing a research project which would both serve the interests of the agency and the broader objectives of the proposed Pesearch project.

In providing a critique of education in Afghanistan it is possible to identify two inter-related social and professional contexts: the first, the changing situation of children and schooling in the country; and second, the world of the donor community operating at national and local level.

\subsection{Context 1: the changing situation of children and schooling in Afghanistan}

"Basic health, education and other social services have collapsed or are extremely precarious at best"

EFA 2000 Afghanistan Draft Final Report, UNESCO p12

The situation of children in Afghanistan is tellingly revealed by the titles on documents and publications, more often than not produced by the major donors and writers dealing with humanitarian assistance.

Phrases such as "Lost chances" (UNICEF, 2001); "Forgotten children" (Children in Crisis, 2001), and "a vanished gender" (Rashid, A "Taliban - Islam, Oil and the New Great Game in 
Central Asia" 2000) reflect a view of the magnitude of the difficulties facing young people growing up in Afghanistan and in the refugee camps outside.

The situation of children is clearly presented in the "' Lost Chances" analysis. It is worth quoting at length UNICEF's overview of the situation for children:

"Traditionally an Afghan child's physical, mental, emotional, social and spiritual development is the responsibility of the extended family unit. The prolonged and ongoing conflict has affected their support at family and institutional level. Afghanistan remains firmly in the lowest rank of education indicators with most Afghans, and especially women, functionally illiterate. The last decade has seen destruction of the remaining urban-based education infrastructure, loss of many qualified staff, and the imposition of increasingly wide-spread restrictions by the Taliban on female employment and education. State-supported formal education is now available only to boys in Taliban-controlled areas while girls can join mosque schools up to the age of 9 years, focussing on religious and moral subjects. Private home- based schools have emerged in urban centres in response to the restrictions and the subsequent deterioration of boys education. By the end of the decade, however, 8 out of every 20 school-age boys (around 2.5 million) and 19 of every 20 girls 2.2 million) across the country were not going to school. Alongside persistent low access to education in Afghanistan is a significant gender gap, an urban/rural divide, and considerable variation in opportunities between different regions of the country. Even where Afghan children have access to education, the quality may be such that there is little learning or overall educational achievement. Capacity, quality and access to primary and higher levels of education, and lack of adequate and longer-term funding remain the primal issues that must be addressed in future education provision".

Though, from a relatively brief visit to the country, this seems an accurate picture of the context in which childrvn and schools re \{ide, it captures $\square$ little of the va $\neg$ ue and energy enÜountered amongstVAfghans when dis $\square$ ussing the educa $\square$ ion of all their children. Time and again reminders would be given of the importance of formal instruction within Afghan and Islamic culture, of the traditional values communities attach to learning, and the special place children hold in the family unit (though gender roles have tended to place a higher value on bÉys who will provÇde for their par $\square$ nts in their oldfage).

Afghanist'n - if one can g- neralise - produ \{es an interestin « situation where communities and cultures, when confronted with political and military authorities hostility to education (particularly of girÀs and women) falà back upon cultuÂal resources forœkeeping alive Eh spirit and príc, ice of educati nr

A research $q^{1} e$;tion that seem ' to be emerging Ñs: to what extenâ can communitiesîcarry the buren of providing $\square$ ducation for the $\square \mathrm{r}$ young children and how effective is that provision?

In the long term serious questions also need to be asked about the development of a national education system, which integrates traditional aspects of community-oriented schooling with the forms of modern training associated with the development of the professions. Given the rural nature of much of the country and the limited resources availabl $\square$ the contributiop of the communitE to the sustainiSg of a national ${ }^{\circledR} y$ stem of education will remain important. 
In other words, though "chances" may be "lost" there seem little evidence that children are either "forgotten" or "vanished". Communities seem willing to invest what they have, even if it is only time and attention, in the education of the next generation.

How effectively they can do that, in the short term at least, appears a legitimate research question.

\subsection{Context 2: the world of the donor community}

The Save the Children/UNICEF Afghanistan 1999 Strategy Paper "Education for Afghans" devotes ten of its sixty pages to (usefully) listing the fifty one "Organizations and Education Projects Assisting the Afghan Education Sector".

The SMU has been established within the broad framework of the Strategic Framework (SF) and the Principled Common Programme (PCP) with the specific objective of using the research process to help the "aid community" gain on better understanding of the broad impact of its programme in Afghanistan in the areas of, "improved livelihoods, access to basic services, progress on human rights issues, and progress towards peace building" (ToRs for the SMU, July $26^{\text {th }} 2000$ ).

Or to put the question more bluntly,

"There are a multitude of agencies in play with respect to Afghanistan with differing objectives, scope and reach or scale ofoperation and geographical coverage. Not surprisingly questions are often asked as to whether they are all pulling in the same direction".

Livelihoods report

March 2001, p2.

This is particularly so in education with agencies providing assistance across the range from "disaster relief" to "long term development goals; community and non-formal education to the provision formal education for grades $1-6$.

A key challenge for an educational research programme, therefore, is to identify core educational issues which relate directly to the work of the particular agency and which are recognised generally as worth investigating.

\subsection{Key donor-assisted educational development programmes}

Meetings were held with staff of selected donor agencies involved in education and based in Peshawar and Kabul. Where possible visits were made to schools, mosques and homes where education was being provided. 
(i) The Winter School Programme in Hazarjat:

Discussion with the Hazarajat Programme Manager and access to evaluation reports.

This is an innovative and largely successful educational initiative in Hazarjat, one of the poorest, rural areas of the country where, during the $3-4$ coldest months of the year when manual work for children has ceased, groups of children (both single sex and mixed groups of boys and girls), are gathered at the village Mosque and local homes to be instructed in reading, writing and basic mathematics.

In his evaluation of the Programme William Gibbs (June 2000) analyses the strengths and weaknesses of Winter Schools:

\begin{tabular}{|c|c|}
\hline & r Schools \\
\hline $\begin{array}{l}\text { Strengths } \\
\text { - } \quad \text { Community support ownership } \\
\text { - } \quad \text { Pleasant learning environment } \\
\text { - } \quad \text { Regular attendance of teachers } \\
\text { and children } \\
\text { - } \quad \text { Classrooms close to home } \\
\text { Concentrated periods of learning } \\
\text { - } \quad \text { Provision of SCF teaching - } \\
\text { learning materials } \\
-\quad \text { Training opportunities for teachers } \\
-\quad \text { Adapted to socio-cultural norms } \\
-\quad \text { Provision of equitable schooling } \\
\text { - } \quad \text { Support and supervision of } \\
\text { teachers by "Social Organisers" } \\
\text { - Open curriculum following national } \\
\text { guidelines but flexible } \\
\text { opportunities to adjust to local } \\
\text { realities }\end{array}$ & $\begin{array}{l}\text { Weaknesses } \\
\text { - } \quad \text { Lack of clear structure of progression } \\
\text { e.g. class } 2 \text { - } 3 \\
\text { - } \quad \text { Under-representation of girls } \\
\text { - } \quad \text { Lack of continuity of learning after } \\
\quad \text { "Winter" } \\
\text { - } \quad \text { Restricted and repetitive teaching } \\
\text { - } \text { methods } \\
\text { - } \quad \text { Diffappropriate texts } \\
-\quad \text { Varieties of record keeping } \\
-\quad \text { Lack of development of women } \\
\quad \text { teachers }\end{array}$ \\
\hline
\end{tabular}

Though Gibbs makes it clear that the Programme provides a legitimate, viable and effective basic education he also makes a number of recommendations linked to improving the learning outcomes of the schools e.g. reviewing the objectives of the schools, developing teachers' methods, appointing and supporting "Master teachers", improving textbooks, developing effective ways to monitor children's learning.

The evaluation report is tantalising in that, though it identifies strengths and weaknesses of the schools, and make sensible recommendations, it leaves open the question of how effective the schools are in producing and sustaining learning outcomes.

An interesting project to research. 
(ii) The Community Organised Primary Eduction (COPE) Project in Logar Province supported by CARE Afghanistan

Extended day's visit to Logar field headquarters, discussions with key staff, and visits to nearby home school.

"COPE's aim is to expand the opportunities for boys and girls to receive quality primary education through the development of community-supported "home schools". The underlying concept is an informal, community-based approach to education. It is low cost, sustainable, and respects local socio-cultural norms, making it especially suitable for Afghanistan".

\section{CARE brochure .}

Field notes of the visit capture the $\square$ quality of provision on the ground and the commitment of the local staff and community members involved:

"CARE seems well organised with excelleåt implementing
$T \quad$ facilities and $\square$ processes. Alsoфsome first rate Yeople on theNground..... the Logar visit show 
can achieve when mobilized and supported on the ground".

The challenge of CARE's work in education concerns the deveUopment of indicayors of quality $\mathrm{O}$ learning outcom $\square \mathrm{s}$. Interestinglw "quality indica+ors" provided by $\ddot{Y} C A R E$ are actuglly quantitativeband relate more so input and provlsion than to out\%out and process.

${ }^{\circ}$ As with the Wintîr Schools PrograËme an opportunity exists to look hard at the effectiveness of what is being provided and to address the question: What progress has there $\square$ een in the learnLng outcomes of t\%oe pupils and howýdo these outcome $\dagger$ relate to assis a ance in the form $\square$ of textbooks, co munity support, teacher training etc?

(iii) The Agricultural Construction Development (ACD) support of formal and vocational scho $\square$ ls in Kabul

Diøccussions with KaÅul-based staff $\mathrm{a} \times \mathrm{d}$ visit to locall̈institutions.

Currently 14,000 pupils within the formal school sector are supported by the ACD who work closely with the Ministry of Educa $\square$ ion and Planning $\square$ A particular fo $\square$ us of the progra ${ }^{\circ} \mathrm{me}$ is the provis $\square$ on of vocationaljtraining (e.g. m7king of shoes, $1-$ ather jackets) for young boys and the employment of teachers within a functioning educational programme.

During the visit to the ACD prXmises in Kabul a 
young male pupil Àspoke of his a formal government-run school. the ACD school e.g. teachers turned "both" schools in case the authorities preference for ACD schooling over attendance at (Though he felt the quality of schooling better at up for work, he, like others, continued to attend suddenly closed down the "parallel school").

Essentially ACD is running a parallel system of 70 schools for boys and 80 home schools for girls with effective us made limited resources. There is, however, limited evidence of effectiveness of learning outcomes, for example, of the use of UNICEF teaching-learning materials.

(iv) - The International Rescue Committee (IRC) community-based education projects, Kabul - The Swedish Committee for Afghanistan (SCA) Schools, Kabul

Discussion with Kabul staff and visits to outlying schools and Mosque-schools"

"A whole generation of Afghans has grown up with virtually no formal education".

I.R.C. Report

Program for Afghans, 1999

A cluster of schools was visited supported by IRC and SCA. 4,600 children are being supported in 160 Home Schools by IRC. The visit to schools in the Kabul district of Bagrami was revealing: the village community provide the teacher's salary (approx. 750 rupees per month and buildings for the school, with the IRC providing teaching aids, textbooks and training for teachers.

Such an arrangement at a time of economic hardship and drought creates difficulties for any medium to long term sustainability and additional problems for agencies who do provide teachers' salaries (i.e. distrust of agencies about what is paid and what is not).

It is also clear that there is a pressing need to link any research programme to the professional and financial needs of teachers whether working in more formal institutions or supported Home Schools. A research initiative orientated towards an Action-Research approach in which teachers research and improve their own practice (and are "paid" a small fee for doing so?) might be a possible way forward.

The SCA-supported schools differ to IRC in that salary subsidies are being paid $(1,050$ Rupees per month - approximately equivalent to US\$ 16 per month). Schools visited showed impressive efforts to provide teaching - learning under difficult circumstances (on the day of the visit to one school on the Logar Road, which had been rehabilitated by the teachers, children were sitting a Mathematics examination).

Again there is an opportunity for this input to be researched with a view to assessing the impact on learning process and outcomes.

(v) UNICEF-Afghan Primary Education Strategy 
Discussions held with senior Kabul based UNICEF staff responsible for the welfare and education of children.

UNICEF are a leading player in this sector focussing their efforts on three "pressing technical needs of Afghan education":

- the need to expand access to education opportunities

- to improve programme quality, and

- to increase local capacity to develop and maintain cost-effective education programmes

In discussion the UNICEF colleagues identified the following "menu" of possible "research areas": quality of textbook provision, the effectiveness of multi-grade teaching, gender disparities, the balance between government-community support, the monitoring of learning effectiveness.

Research, from UNICEF's point of view could provide an opportunity to stand back and look at the "bigger picture" e.g. what impact is aid to edûcation having,or learning outcomes? Such a research programme, they suggested, might investigate ihputs and processes currently provided by the authorities, agencies and the community. UNICEF have a particular role in the development of learning materials, provision of teacher training and upgrading, and the development of more reliable knowledge base i.e. through Education Management Information System (EMIS).

\subsection{The co-ordination of Educational Provision in Afghanistan}

An opportunity was provided to meet members of the Education Task Force (ETF), a forum of representatives from the donor community in Kabul. During a lively session on the potentials and challenges in establishing a research programme it was proposed that at its next meeting members identify priority research topics relevant to the work of each agency and possible "common themes" that might form the core of such a research programme.

The Agency Co-ordinating Body for Afghan Relief (ACBAR) have also established an Education Working Group (EWG) based in Peshawar. Discussion with the group's chairperson was also useful, and indicates that co-ordination is seen as an important issue within and without the country; and also that a means exists for the result of research to be effectively shared and disseminated.

\subsection{Summary of the situation}

- though conditions for learning in Afghanistan are difficult there is evidence that schooling is still valued and sought,

- the hostility of the authorities towards formal schooling, particularly of girls, has created opportunities for community innovation and leadership of educational provision, 
- the proliferation of donor agency work in education has created a "parallel education" system: formal and non-formal with some children experiencing both as a form of "insurance",

- the different approaches of the donor agencies to their role e.g. short term emergency assistance, longer term developmental work means that a research programme will need to identify core educational issues common and useful to the stakeholders

- the projects and programmes visited and reviewed here are generally impressive in the inputs provided and in the calibre of personnel involved. A general need (and challenge) seems to be in the evaluation of learning outcome in relation to inputs and processes

- Mechanisms for the co-ordination of educational provision within and without the country have been established and offer a vehicle for sustaining, sharing and disseminating research work.

\section{The Language of Possibility: proposals for a research programme in education}

\subsection{The Proposal}

Given the complexity and the rapidly changing socio-political situation in Afghanistan it seems possible to establish a research programme that will:

1) provide an in-depth analysis of the strengths and weaknesses in terms of learning outcomes of selected donor-assisted projects in education,

2) by means of a small number of case studies investigate such projects with a view to generalising insights and solutions to common educational problems across the sector and to the more general development needs of the country (and people living outside it)

3) be both specific in taking account of local issues and activities and national in relating to a set of common core educational themes relevant to all the cases

4) draw upon existing capacity to be found within the agencies in terms of personnel, logistical support, and interest

5) produce findings which directly relate to the differing needs of the donor community, teachers and parents and children

6) develop research capacity at national and local level - along the lines of the Action Research tradition.

\subsection{Overview}


Three ( probably, final decision on numbers to be made later) donor-assisted case studies be investigated with a view to gathering data on the effectiveness of learning outcomes e.g.

5 


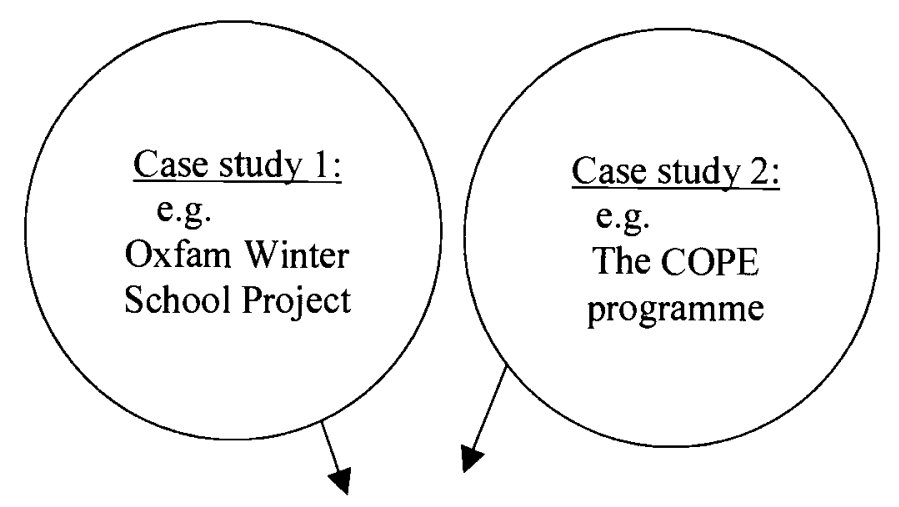

Research area: "The effectiveness of learning outcomes".

Note: case studies are examples, not a final decision.

\section{Criteria of case studies:}

Continuing thought will need to be given to the criteria of selection of the case studies. At the moment it seems important to bear in mind the following criteria when selecting the cases:

a) NGO/Agency input is sustained and committed in the particular case e.g. CARE schools, Oxfam Winter Schools

b) Contrasting and comparable variables are accounted for e.g. use of UNICEF resources, urban-rural settings

c) Good people on the ground, with the appropriate experience and skills, have been identified.

d) The research sites are accessible and safe etc.

Much has been written internationally on learning outcomes and school effectiveness. The most useful conceptual framework for investigating factors that determine effectiveness is given below: 
The School:

Factors Related to Effectiveness

\section{School Climate}

- High Expectations of Students

- Positive Teacher Attitudes

- Order and Discipline

- Organized Curriculum and Community Support

- Effective Support from the Education System

- Adequate Material Support Frequent and Appropriate Teacher Development Activities Sufficient Textbooks and other Materials Adequate Facilities

\section{Enabling Conditions}

- $\quad$ Effective Leadership

- A Capable Teaching Force

- Flexibility and Anatomy

- High Time-in-School

\section{Student Outcomes}

- Participation

- Academic Achievement

- Economic Success

Teaching/Learning Process CONTEXTUAL FACTORS

- International

- Cultural trategies

- Political

- Economic

Figure 5.1 Conceptual framework: factors that determine school effectiveness Source: Heneveld (1994)

Such a model has value in that it could be adapted to meet particular local circumstances and the characteristics of a particular project being investigated. A particular strength of this model is the emphasis given to the relationship of learning outcomes to supporting inputs and enabling conditions (sometimes called "process factors").

\section{$3.3 \quad$ Goal}

Raising the quality of educational provision to Afghan children within Afghanistan (Taliban and non-Taliban areas) and among refugees outside the country is a goal shared by the agencies and the SMU. In particular quality can be specified in terms of the relationships between "supporting inputs", "enabling conditions" and "student learning outcomes". The continued investment by the agencies into supporting community efforts through the design and implementation of innovative programmes, improved textbooks, etc. calls for a research programme oriented towards effectiveness of intended outcomes. 


\subsection{Methodological note}

School effectiveness research elsewhere has demonstrated the value in adopting a broadly qualitative research strategy with close involvement of the participating teachers. Given the problem of teacher salaries in Afghanistan there is a case to be made for such research to fully involve the teachers (and community leaders) and to look to ways to pay individuals a modest fee for taking part.

\subsection{Purpose}

The purpose of this project is to ensure that the agencies and authorities providing education are better informed of the consequences and impacts of various inputs upon the student learning outcomes in specific contexts. Comparisons and contrasts drawn from the research findings across the cases will provide Afghan stakeholders with evidence of what works and what does not. Such generalisations will be tempered by the realisation that education is located in and best serves the interests of children when rooted in the local and known.

$$
5
$$

A subsidiary purpose of the project is to provide the agencies and SMU with enhanced research eapacity. Conducting qualitative case study research is a skilled and sensitive activity. Opportunities exist, however, to develop a cadre of researchers competent and capable, perhaps working within Active Research traditions (e.g. teachers researching their own classrooms, donor agency staff investigating their own professional activity).

\subsection{Outputs and their contribution}

The project will deliver the following outputs:

1) Impact of supporting inputs to education in identified cases study projects assessed for effectiveness of student learning outcomes

Following further discussions by the SMU with NGO's and multilateral/bilateral agencies the case studies will be identified for inter-linked research into the effectiveness of interventions and inputs. Care will need to be taken in the selection of case studies, the identification of "core themes" to be assessed, and the relationship of he research to on-going project evaluations.

2) Research capacity of key agencies engaged in development of Afghan education enhanced

Bearing in mind the objective of the SMU and agencies to develop and sustain capacity to produce knowledge and understanding of the processes and outputs of educational initiatives it is important to build up a skilled and interested group of researchers.

There is also an opportunity to empower teachers and community teachers by adopting research strategies along Action Research lines. 


\subsection{Activities}

\section{For output 1}

OP1 1. Further visits to non-Taliban areas and refugee communities in Pakistan to identify appropriate case study sites

Discussions and negotiations will be required to identify suitable sites for the research. In particular attention will need to be given to issues of comparability e.g. assessment of supporting inputs, access, and co-ordination with donor monitoring and evaluation.

\section{OP1 2. Review of existing sources of data}

In identifying first, research sites; and second the core themes to be investigated a thorough review of existing data and documentation will be critically undertaken.

OP1 3. Establishment Development of a national educational documentary archive

Currently documentary evidence pertaining to educational work still appears scattered through project offices. Consideration will need to be given to further developing the smallarchive of useful documents, evaluation reports, etc at SMU.

\section{OP1 4. Identification and establishment of a research management team}

Subject to successful negotiation with the NGOs and agencies it will be necessary to recruit a research co-ordinator with sufficient and appropriate knowledge and skills to carry out the project. Ideally he or she will be familiar with the likely research sites and will be based in a convenient location with regard to access.

The establishment of a research team will need to follow discussions with the participating agencies, particularly with a view to identifying existing research capacity e.g. research- experienced local staff. At this stage it is important that key tasks and required skills and competencies be identified and that the broad levels of commitment of the agencies to the proposed research programme.

OP1 5. Support to the collection, analysis and dissemination of findings

SMU to support the process of data collection, data analysis and communication of findings. Negotiation will be held with existing education co-ordinating bodies: the ETF and EWG to assist in the facilitation of this activity.

\section{For output 2}

OP2 1. Audit and needs assessment exercise of participating NGO's and bilateral multilateral agencies.

An audit be carried out of participating agencies with a view to identifying key staff competencies, experience upon which to build capacity. 
OP2 2. Discussion and negotiations be maintained with the ETF and EWG re development of a "critical friend" role

The ETF and EWG assume the role of "critical friend" to the project. Equally the participating NGOs and agencies consider the research activities central to their own evaluation of the respective projects.

\section{OP2 3. Support of research capacity building}

Discussion and negotiation with interesting parties e.g. DFID Islamabad in the support of research. Such support might take the form of regional training workshops, the supply of "teacher-research" materials, the dissemination of findings for the benefits of communities elsewhere facing similar challenges.

\section{$3.8 \quad$ Beneficiaries}

The potential beneficiaries will be found at all levels of the educational and social system: at local, case study level teachers, parents and students will benefit from a closer synergy between input and learning output; teachers in particular will gain enhanced professional understanding of their teaching-learning strategies; and supporting agencies and field workers will be better informed by substantial critical analysis of their support to education. At a national level lessons will be learnt of what is working in terms of educational effort; with some indication of effective strategies upon which to base a national educational system.

\subsection{Risks and assumptions}

It is clear that education operates within an unstable and unpredictable political and economic environment. The number and diffuseness of the NGO's and agencies' also challenge the desire for coherence and sense of direction to educational improvement.

However, visits to the agencies and projects provide evidence that the will to carry out manageable, focussed and "project-useful" research exists. Such will needs to be supported by continued donor support in the medium and long term.

\section{Professor David Stephens,}

August, 2001 


\section{Outline Log Frame for an Education Research Program}

\begin{tabular}{|c|c|c|}
\hline Narrative Summary & Measurable Indicators & Means of Verification \\
\hline $\begin{array}{l}\text { Goal } \\
\text { Improved quality of education of } \\
\text { Afghan children }\end{array}$ & $\begin{array}{l}\text { Positive changes in the learning } \\
\text { and teaching of students and } \\
\text { teachers in terms of processes and } \\
\text { outcomes }\end{array}$ & Multi-site case study \\
\hline $\begin{array}{l}\text { Purpose } \\
\text { Interventions to raise the quality of } \\
\text { education are informed by lessons } \\
\text { learnt from school effectiveness } \\
\text { studies }\end{array}$ & $\begin{array}{l}\text { Assessment of changes in learning } \\
\text { outcomes to inform supporting } \\
\text { inputs in } 3 \text { sites. Assessment of } \\
\text { outcomes in } 3 \text { sites to guide } \\
\text { interventions at future and national } \\
\text { level }\end{array}$ & $\begin{array}{l}\text { Agency reports, teacher reports, } \\
\text { children's work/output }\end{array}$ \\
\hline $\begin{array}{l}\text { Outputs } \\
\text { 1. Inputs to education in selected } \\
\text { sites assessed for learner- } \\
\text { outcómes effectiveness } \\
\text { 2. Research capacity at national } \\
\text { and local level established and } \\
\text { enhanced }\end{array}$ & $\begin{array}{l}\text { Teacher-researches } \\
\text { Case studies established } \\
\text { Qualitative, context-sensitive } \\
\text { investigation undertaken } \\
\text { Document archive established } \\
\text { Small research teams established }\end{array}$ & Report \\
\hline
\end{tabular}




\section{$\underline{\text { Appendix B }}$}

\section{Organisations and People met}

1. Kefayatullah Eblagh, Director Afghan Technical Consultants

2. Prof. Dr. Alef Shah Zadran, CARE Afghanistan

3. Hassan Mohamed, Education Program Coordinator CARE. Afghanistan

4. Sally Austin, Ass. Country Director, CARE Afghanistan

5. Mr Waleed and colleagues CARE Field Staff Logar

6. Jurgen Bolser, Education Adviser, Swedish Committee for Afghanistan

7. Azimullah Hafizi, Director, Agricultural Construction Development, Kabul

8. Mr. Shah Wali, Hazarajat Programme Manager, Oxfam Afghanistan.

9. SCA supported schools, Logar Road, Kabul

10. Gul Habib, International Rescue Committee, Kabul

11. I.R.C. supported schools, Bagrami district, Kabul

12. Dr. A.S. Ghafoori, Ass. Project Officer, UNICEF Afghanistan.

13. Ms. Ellen van Kalmthout, Project Officer Child Development, UNICEF Afghanistan

14. Jonathan Rennison, Programme Manager, Children in Crisis Afghanistan.

15. Helen Kirby, Education Advisor, Save the Children USA, Pakistan/Afghnistan.

16. Barnáby Willitts-King, Programme Officer, Conflict and Humanitarian Affairs Dept. DFID. British High Commission Islamabad.

17. Dr. Adam Pain, Livelihoods Adviser SMU Afghanistan

18. Chris Johnson, Director SMU Afghanistan. 